Insight Pharmaceutical Sciences 1 (2): 18-23, 2011

ISSN 2040-705X

(C) 2011 Insight Knowledge, UK

\title{
Thermal Characterization of Leflunomide
}

\author{
${ }^{1}$ M.A. El-Ries, ${ }^{1}$ F.M. Abo-Attia, ${ }^{2}$ A. EL-Bayoumi and ${ }^{1}$ G.S. Eman \\ ${ }^{1}$ National Organization of Drug Control and Research (NODCAR), 35521, Giza, Egypt \\ ${ }^{2}$ Department of Analytical Chemistry, Faculty of Pharmacy, Cairo University, Cairo, Egypt
}

\begin{abstract}
Purpose: The aim of the present work is to study the thermal behavior of leflunomide drug substance and drug product. Methods: Differential Thermal Analysis (DTA), Differential Scanning Calorimetry (DSC) and thermogravimetric analysis (TG/DTG) determined the raw material's purity, kinetic parameters, thermal behavior and melting characteristics. The thermogravimetric data allow determination of kinetic and thermodynamic parameters: Activation energy $\left(\mathrm{E}_{\mathrm{a}}\right)$, activation entropy $\left(\mathrm{AS}^{*}\right)$ and reaction order $(\mathrm{n})$ which calculated from TG-curves at different heating rates using different kinetic models: The relative thermal stability of the drug has been evaluated on the basis of the kinetic and thermodynamic parameters. Also, the purity of the drug is determined by Differential Scanning Calorimetry (DSC) technique. Results: The value of purity found is $99.997 \pm 0.09 \%$. Quality control parameters obtained from the thermal analysis of leflunomide are melting point $164.42^{\circ} \mathrm{C}$, water content $0 \%$ and ash content $0 \%$. Conclusion: The simplicity, speed and low operational costs of thermal analysis justify its application in quality control of pharmaceutical drugs. DSC data indicated that the degree of purity of leflunomide is similar to that found by official methods.
\end{abstract}

Key words: Leflunomide, DSC, TG, DTG, DTA, vamid tablet, quality control

\section{INTRODUCTION}

Leflunomide is a pyrimidine synthesis inhibitor belonging to the DMAR (disease-modifying antirheumatic drug) class of drugs, which are chemically and pharmacologically very heterogeneous. Leflunomide, 5-methy-N-[4-(trifluoromethy1) pheny1]-4isoxazolecarboxamide (Budavari et al., 2006; USP, 2009).

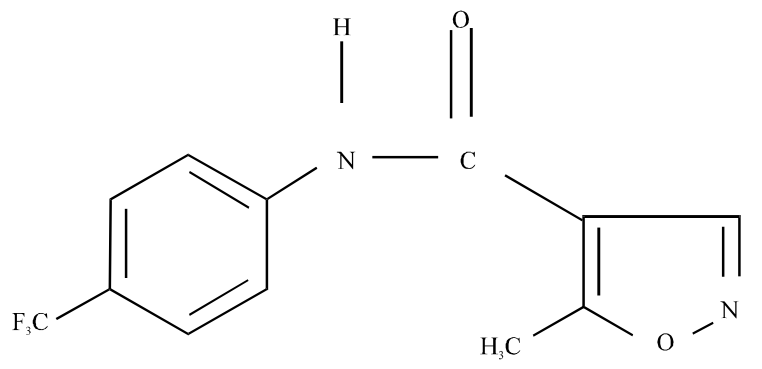

Leflunomide has immunosuppressant properties. It is used as a disease-modifying anti rheumatic drug in the treatment of active rheumatoid arthritis and also in the treatment of active psoriatic arthritis. It is being investigated in the management of various solid neoplasm (Martindale, 2009). It is well absorbed after oral administration. Leflunomide is a prodrug that is rapidly metabolized in the liver via opening of the isoxazole ring to the active metabolite and then excreted urine and feces (Manna et al., 1999; Martindale, 2009).

Various methods have been mentioned in literature for the analysis of leflunomide in pure form, in pharmaceutical formulations and in biological fluids such as spectrophotometric method (Yenicelia et al., 2005) and chromatographic methods (Dias et al., 1995); Fairbanks et al., 1999; Schmidt et al., 2003; Roon et al., 2004; Chan et al., 2004; Yenicelia et al., 2005).

The thermoanalysis methods refer to a group of techniques in which a physical property of a substance and/or its reaction products is measured as a function of a controlled temperature program (Giron, 2002). The most widely used techniques are Differential Thermal Analysis (DTA), Differential Scanning Calorimetry (DSC) and thermogravimetry/derivative thermogravimetry (TG/DTG). These techniques are widely used in the pharmaceutical sciences for the characterization of solid drugs and excipients. These techniques are established for quality control, preformulation, stability, drug-excipients interactions, polymorphism and purity studies of raw materials and pharmaceutical products (Mashru et al., 2005; Xu et al., 2006; Vega et al., 2006; Saliva et al., 2007; Ning and $\mathrm{Xu}, 2010$ ).

Corresponding Author: M.A. El-Ries, National Organization of Drug Control and Research (NODCAR), 35521, Giza, Egypt 


\section{MATERIALS AND METHODS}

Materials: Leflunomide, raw material and Vamid ${ }^{\circledR}$ tablets were provided from ALKAN PHARMA, S.A.E., Co.S.A.E. 6th of October city, EGYPT. Each tablet is labeled to contain $100 \mathrm{mg}$ of Leflunomide with batch No. 008 .

\section{Methods}

Thermogravimetric analysis (TG) and differential thermal analysis (DTA): TG/DTG and DTA studies were made with simultaneous DTA-TG-Shimadzu DTG-60 H thermal analyzer. Approximately $5 \mathrm{mg}$ of samples, using a platinum pan, were carried out from ambient temperature to $800^{\circ} \mathrm{C}$ in dynamic nitrogen atmosphere with the flow rate of $30 \mathrm{~mL} \mathrm{~min}^{-1}$ and heating rate of $10^{\circ} \mathrm{C} \mathrm{min}^{-1}$.

Differential scanning calorimetry (DSC): DSC curves were measured on Shimadzu DSC-50 cell. Approximately $2 \mathrm{mg}$ of samples were mass out and placed in a sealed aluminum pan. An empty aluminum pan was used as a reference. The purity determination was performed using heating rate of $2^{\circ} \mathrm{C} \mathrm{min}^{-1}$ in the temperature range from 25 to $185^{\circ} \mathrm{C}$ in nitrogen atmosphere with flow rate

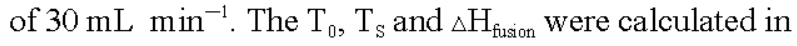
three replicates by Shimadzu TASYS software. DSC equipment was preliminary calibrated with standard of indium.

Kinetics: Solid state reactions include phase transition such as melting, evaporation and sublimation, as well as decomposition reactions resulting in the production of different compounds. Thermal analysis can be used to monitor these reactions by determining the rate of mass loss as the sample undergoes the process, using simultaneous TGA-DTA with a rising temperature program. The specific rate constant and the kinetic mechanism are determined with experimental data obtained from the TGA plot $\%$ mass loss versus time or temperature and the derivative analysis (DTG) plot of rate of mass loss $(\mathrm{dm} / \mathrm{dt})$ versus time or temperature. The specific rate constants are determined by Eq. 1:

$$
\mathrm{K}=[(\mathrm{d} \alpha / \mathrm{dt}) \beta] / \mathrm{f}(\alpha)
$$

where, $\alpha$ is the fraction reacted and $\beta$ is heating rate in degrees/sec. the term $\mathrm{f}(\alpha)$ can be obtained from tables of different mechanisms. For the first order mechanism, it is equal to $(1-\alpha)$. The Arrhenius equation is used to calculate the activation energy:

$$
\ln \mathrm{K}=\ln \mathrm{A}-\mathrm{E}_{\mathrm{a}} / \mathrm{RT}
$$

where, $\mathrm{K}$ is the specific rate constant, $\mathrm{E}_{\mathrm{a}}$ is the activation energy, $\mathrm{R}$ is gas constant, $\mathrm{A}$ is the pre-exponential term and $\mathrm{T}$ is the temperature in Kelvin. A plot of $\ln \mathrm{K}$ versus $1 / \mathrm{T}$ is linear with a slope equal to $\mathrm{E}_{\mathrm{a}} / \mathrm{R}$ and an intercept equal to $\mathrm{A}$.

\section{RESULTS AND DISCUSSION}

TG/DTG and DTA curves of the leflunomide are seen in Fig. 1 and 2 TG/DTG curves show two thermal decomposition steps. The first step shows a large mass loss of $91.63 \%$ (found $89.5 \%$ ) in the range of $170-262.59^{\circ} \mathrm{C}$. In addition a mass loss of $8.4 \%$ (found $10.3 \%$ ) is observed in the interval $262-400^{\circ} \mathrm{C}$ as shown in Table 1 . The first thermal decomposition step is suggested to be due to the elimination of $\left(\mathrm{C}_{11} \mathrm{H}_{9} \mathrm{~F}_{3} \mathrm{~N}_{2} \mathrm{O}\right)$. The second thermal decomposition step is may be due to the elimination of $\mathrm{C}=\mathrm{O}$ group. The decomposition is confirmed by DTA curve that indicates two endothermic peaks in temperature range $\left(165.8-176.15^{\circ} \mathrm{C}\right)$ and $\left(232.23-250.8^{\circ} \mathrm{C}\right)$ as shown in Table 2. DTA curve shows an endothermic peak at $168.4^{\circ} \mathrm{C}$ (reported range $164-168^{\circ} \mathrm{C}$ ). This event may be corresponding to the melting of the compound. DSC gives a value of $164.4^{\circ} \mathrm{C}$ for melting point.

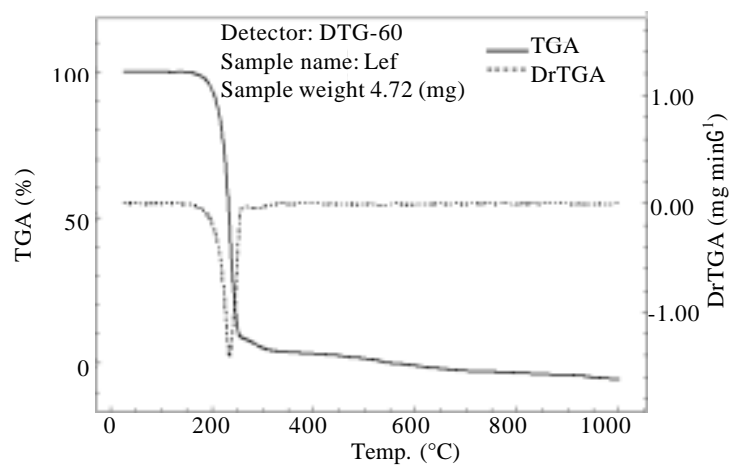

Fig. 1: TG/DTG curves of leflunomide

\begin{tabular}{|c|c|c|c|c|c|c|c|}
\hline \multicolumn{4}{|c|}{ First reaction } & \multicolumn{4}{|c|}{ Second reaction } \\
\hline $\begin{array}{l}\text { Start } \\
\left({ }^{\circ} \mathrm{C}\right)\end{array}$ & $\begin{array}{l}\text { End } \\
\left({ }^{\circ} \mathrm{C}\right)\end{array}$ & $\begin{array}{l}\text { wt. loss } \\
(\%)\end{array}$ & $\begin{array}{l}\text { DTG } \\
\text { Peak }\end{array}$ & $\begin{array}{l}\text { Start } \\
\left({ }^{\circ} \mathrm{C}\right)\end{array}$ & $\begin{array}{l}\text { End } \\
\left({ }^{\circ} \mathrm{C}\right)\end{array}$ & $\begin{array}{l}\text { wt. loss } \\
(\%)\end{array}$ & $\begin{array}{l}\text { DTG } \\
\text { Peak }\end{array}$ \\
\hline 170.45 & 262.59 & 91.6 & 236.34 & 262 & 400 & 8.5 & 299 \\
\hline
\end{tabular}

Table 1: Thermo gravimetric reaction

\begin{tabular}{|c|c|c|c|c|c|c|c|}
\hline \multicolumn{4}{|c|}{ First reaction } & \multicolumn{4}{|c|}{ Second reaction } \\
\hline $\begin{array}{l}\text { Start } \\
\left({ }^{\circ} \mathrm{C}\right)\end{array}$ & $\begin{array}{l}\text { End } \\
\left({ }^{\circ} \mathrm{C}\right)\end{array}$ & $\begin{array}{l}\text { wt. loss } \\
(\%)\end{array}$ & $\begin{array}{l}\text { DTG } \\
\text { Peak }\end{array}$ & $\begin{array}{l}\text { Start } \\
\left({ }^{\circ} \mathrm{C}\right)\end{array}$ & $\begin{array}{l}\text { End } \\
\left({ }^{\circ} \mathrm{C}\right)\end{array}$ & $\begin{array}{l}\text { wt. loss } \\
(\%)\end{array}$ & $\begin{array}{l}\text { DTG } \\
\text { Peak }\end{array}$ \\
\hline Endo & 165.8 & 168.43 & 176.15 & Endo & 232.23 & 243.15 & 250.85 \\
\hline
\end{tabular}

Table 2: DTA reactions 
Insight Pharmaceutical Sciences 1 (2): 18-23, 2011

Table 3: Thermodynamic parameters for the thermal decomposition of leflunomide

\begin{tabular}{lllllcc} 
& & \multicolumn{3}{c}{ Thermodynamic parameters } & & \\
Methods & Temperature range $\left({ }^{\circ} \mathrm{C}\right)$ & $\mathrm{E}_{\mathrm{a}}\left(\mathrm{kJ} \mathrm{mol}^{-1}\right)$ & $\mathrm{A}\left(\mathrm{S}^{-1}\right)$ & $\Delta \mathrm{S}\left(\mathrm{kJ} \mathrm{mol}{ }^{-1} . \mathrm{K}\right)$ & $\Delta \mathrm{H}\left(\mathrm{kJ} \mathrm{mol}{ }^{-1}\right)$ & $\Delta \mathrm{G}\left(\mathrm{kJ} \mathrm{mol}{ }^{-1}\right)$ \\
\hline Coats -Redfern & $170.5-262.6$ & 111.835 & $6.1 \times 10^{11}$ & -22.478 & 108.198 & 118.024 \\
Horowitz and Metzger & $170.5-262.6$ & 97.317 & $2.61 \times 10^{11}$ & -29.54 & 93.682 & 106.595 \\
\hline
\end{tabular}

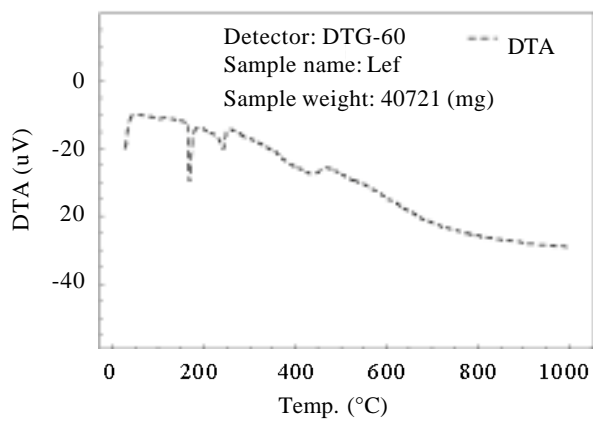

Fig. 2: DTA curve of leflunomide

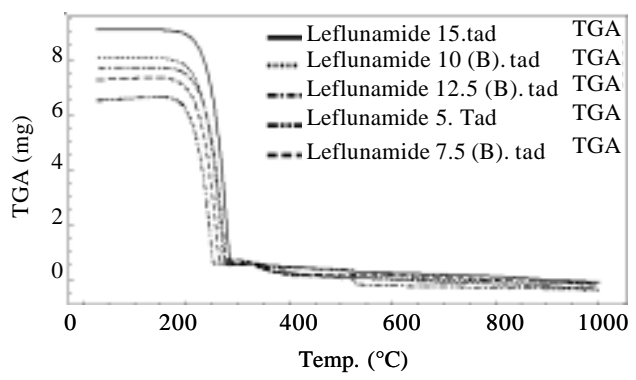

Fig. 3: TG curves obtained at $5,7.5,10,12.5,15^{\circ} \mathrm{C} \mathrm{min}^{-1}$ in $\mathrm{N}_{2}\left(30 \mathrm{~mL} \mathrm{~min}^{-1}\right)$

\section{Non-isothermal kinetic study}

Ozawa's method: Non-isothermal kinetic study is performed by the application of Ozawa's method (Ozawa, 2000). In dynamic experiments heating rates of 5 , $7.5,10,12.5,15^{\circ} \mathrm{C} \mathrm{min}^{-1}$ were used to target temperature $800^{\circ} \mathrm{C}$ as shown in Fig. 3, in order to determine the activation energy $(E)$, Arrhenius frequency factor $(Z)$ and order of reaction (n). The equipment was preliminarily calibrated with standard reference of calcium oxalate. The effect of heating rates were described to drug captopril (Huang et al., 2001). The activation energy was obtained from a plot of logarithms of heating rates (A) as a function of the inverse of temperature (1/T) for a constant $\mathrm{G}(\mathrm{x})$, where $\mathrm{G}(\mathrm{x})$ is the integrated form of the conversion dependence function, $\mathrm{f}(\mathrm{x})$ (Fig. 4). The kinetics parameters obtained were activation energy (E) in $\mathrm{kJ} \mathrm{mol}{ }^{-1}$, frequency factor $(\mathrm{Z}) \mathrm{min}^{-1}$ and zero order reaction $(\mathrm{n}=0)$.

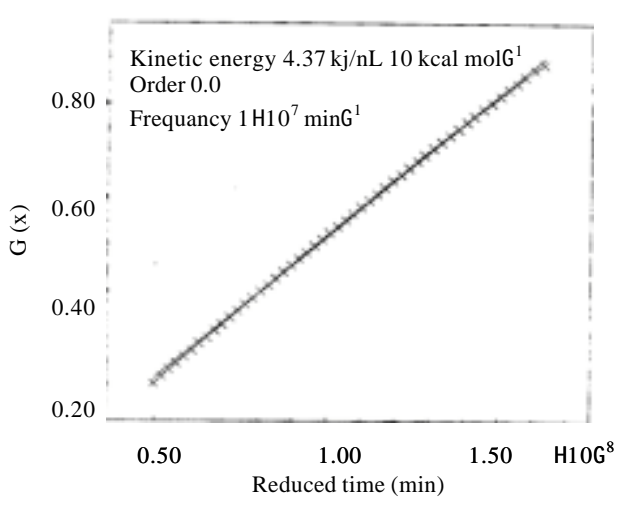

Fig. 4: Integrated form of constant $\mathrm{G}$ (x) and the convention dependence function

Horowitz and Metzger method: For the first order kinetic process, the Horowitz-Metzger equation (Horowitz and Metzger, 1963).

Coats-Redfern method: For the first order kinetic process, the activation energy $\left(E_{a}\right)$ in $J /$ mole could be calculated from Coats-Redfern equation (Coats and Redfern, 1964). The entropy $\Delta \mathrm{S}^{*}$, enthalpy $\Delta \mathrm{H}^{*}$ and free energy $\Delta \mathrm{G}^{*}$ of activation were calculated using the following equations:

$$
\begin{gathered}
\Delta \mathrm{S}^{*}=2.303[\log (\mathrm{Ah} / \mathrm{kT})] \mathrm{R} \\
\Delta \mathrm{H}^{*}=\mathrm{E}^{*}-\mathrm{RT} \\
\Delta \mathrm{G}^{*}=\mathrm{H}^{*}-\mathrm{T}_{\mathrm{s}} \Delta \mathrm{S}^{*}
\end{gathered}
$$

where, $\mathrm{k}$ and $\mathrm{h}$ were the boltzman and plank constant, respectively. So, the calculated values of $\mathrm{E}^{*}, \Delta \mathrm{S}^{*}, \Delta \mathrm{H}^{*}$ and $\Delta \mathrm{G}^{*}$ could be obtained as shown in Table 3 .

Determination of purity: The determination of purity is based on the assumption that an impurity will depress the melting point of a pure material whose melting is characterized by a melting point $\left(\mathrm{T}_{0}\right)$ and an enthalpy of fusion $\left(\Delta \mathrm{H}_{\mathrm{f}}\right)$. The melting transitions of a pure, $100 \%$ crystalline material should be infinitely sharp, but impurities or defects in the crystal structure will broaden the melting range and lower the final melting point to a temperature lower than $\mathrm{T}_{0}$ (Hatakeyama and Liu, 1998). Purity determination is officially listed in United 


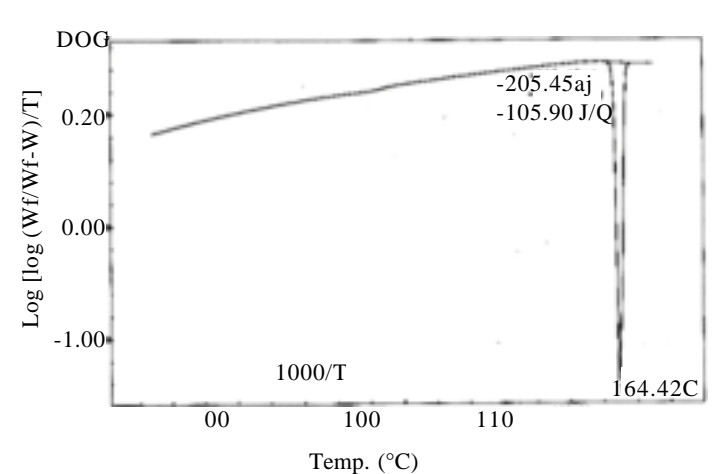

Fig. 5: DSC curve obtained at heating rate of $2^{\circ} \mathrm{C} \mathrm{min}^{-1}$ in $\mathrm{N}_{2}\left(30 \mathrm{~mL} \mathrm{~min}^{-1}\right)$ of leflunomide

Table 4: Melting points and degrees of purity of the drug

\begin{tabular}{|c|c|c|c|c|c|}
\hline \multicolumn{3}{|c|}{ Melting point } & & \multicolumn{2}{|c|}{ Degree of purity (\%) } \\
\hline TA & $\begin{array}{l}\text { Melting* } \\
\text { point apparatus }\end{array}$ & & & & Of \\
\hline 168.4 & 164 & 164.42 & $164-168^{* * *}$ & $99.997 \%$ & $99.89 \%$ \\
\hline
\end{tabular}

*Mettler FP 80, central processor, ** USP 32, ***HPLC

Table 5: Quality control parameters obtained from the thermal analysis of leflunomide compared with reported method (USP, 2009)

\begin{tabular}{lcc}
\hline Parameters & Thermal analy sis & Reported method \\
\hline Melting point $\left(164-168^{\circ} \mathrm{C}\right)$ & $164.42^{\circ} \mathrm{C}$ & $164^{\circ} \mathrm{C}$ \\
Loss on dry ing (NMT 0.5\%) & Zero $\%$ & $0.09 \%$ \\
Ash content (NMT 0.1\%) & Zero $\%$ & Zero $\%$ \\
\hline
\end{tabular}

Instruments: melting point (Mettler FP 80, central processor), (Precisa XM 60 , swiss made) for loss on drying and muffle fumace (Vulcan A-550) for ash content

States Pharmacopoeia in general chapter on thermal analysis (USP, 2009). The effect of an impurity on $T_{0}$ of Leflunomide was determined by DSC method basing on the Van't Hoff equation:

$$
\frac{\mathrm{T}_{\mathrm{s}}=\mathrm{T}_{0} \mathrm{RT}_{0}^{2} \times 1 / \mathrm{F}}{\Delta \mathrm{H}_{\mathrm{f}}}
$$

where, $\mathrm{T}_{s}$ is the sample temperature at equilibrium $(\mathrm{K}), \mathrm{T}_{0}$ is the melting point of the pure component $(\mathrm{K}), \mathrm{R}$ is the gas constant, $\mathrm{X}$ is the concentration of impurity (mole fraction) and $\mathrm{F}$ is the fraction molten at $\mathrm{T}_{s}$.

The obtained DSC curve is shown in Fig. 5, which exhibits the endothermic event corresponding to leflunomide's melting point $\left(\Delta \mathrm{h}_{\mathrm{f}}=105.90\right)$. The value of purity found was $99.997 \%$ confirming low impurity content, also data was compared with official method in Table 4.

Application of thermal analysis to quality control of leflunomide: Thermal analysis is used as an alternative technique for laboratory-screen tests (long-term tests),

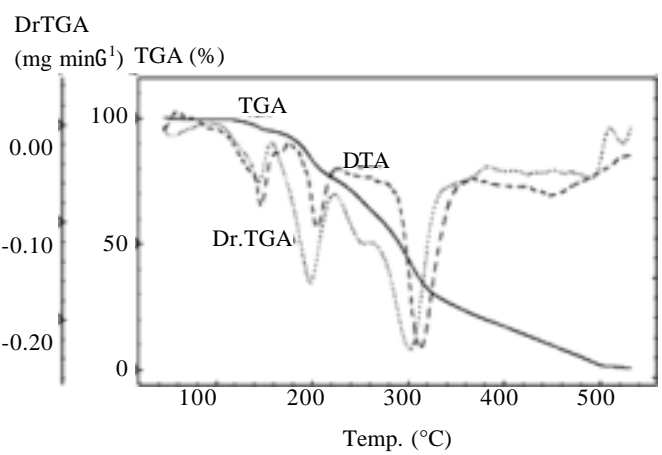

Fig. 6: Thermal analysis (TG, DTG and DTA curves) of vamid tablet

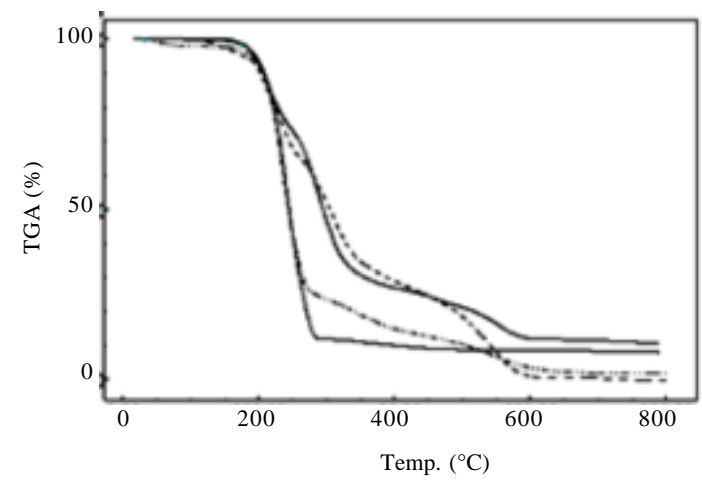

Fig. 7: TG thermogram of leflunomide alone (-) and with different excipients, Lactose monohydrate (----), Mg stearate (-) and crosspovidone (-..-..)

for the determination of different quality parameters such as, melting point, water content and ash content. No significant difference was observed between the obtained results when compared with reported method as shown in Table 5.

Application of thermal analysis to vamid tablet: DTA, DTG and TG curves of leflunomide formulation are seen in Fig. 6. The thermal degradation occurs in three steps and the onset and endest temperature for degradation was shifted to lower temperature. DTA evidence an endothermic peak corresponding to leflunomide melting point in temperature range of 150 to $160^{\circ} \mathrm{C}$ followed by thermal decomposition. This is confirmed by TG curve that indicate mass loss event. It was observed that the drugs melting event occurs with mass loss, suggesting an interaction, but not necessary corresponding to incompatibility. In fact a similar effect was observed for other drug excipients mixtures and was attributed to drug dissolution in the melted excipients (Cides et al., 2006). 


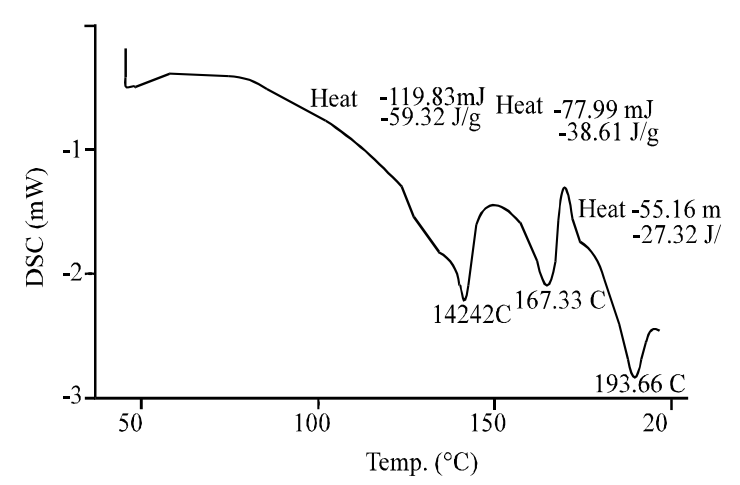

Fig. 8: DSC curve obtained at heating rate of $2^{\circ} \mathrm{C} \mathrm{min}^{-1}$ in $\mathrm{N}_{2}\left(30 \mathrm{~mL} \mathrm{~min}^{-1}\right)$ of leflunomide tablet

Based on the results of $\mathrm{TG}$, majority of the excipients (mg stearate, lactose monohydrate and crosspovidone) were found to be compatible with leflunomide as shown in Fig. 7. The drug was found to be stable up to $200^{\circ} \mathrm{C}$ in the presence of excipients.

Also the DSC curve of leflunomide tablet (Fig. 8) shows an endothermic peak at $67^{\circ} \mathrm{C}$ corresponding to melting point of leflunomide's melting point.

\section{CONCLUSION}

In the development of solid pharmaceutical forms, quality control, stability and compatibility studies are important parameters to ensure the final product quality. Thermoanalysis is a routine method current applied in pharmaceutical industry.

DSC provides a rapid method for purity determination, attending value between 98 and 102\%, which is in agreement with the official published method. The decomposition process occurs in constant rate and is independent of the concentration of the reactants. When the limiting reactant is completely consumed the reaction abrupt stops. The excipients can produce a different environment in which the behavior of the drug is modified but they are still compatible with the drug.

\section{REFERENCES}

Budavari, S., M.J. Oneil and A Smith, 2006. The Merck Index: An Encyclopedia of Chemicals, Drugs and Biologicals. 14th Edn., Merck and Co., Rahway, New Jersey, ISBN: 0911910263 , pp: 1756.

Chan, V., B.G. Charles and S.E. Tett, 2004. Rapid determination of the active leflunomide metabolite A77 1726 in human plasma by highperformance liquid chromatography. J. Chromatogr. B, 803: 331-335.
Cides, L.C.S., A.A.S. Araujo, M. Santos-Filho and J.R. Matos, 2006. Thermal behaviour, compatibility study and decomposition kinetics of glimepiride under isothermal and non-isothermal conditions. J. Therm. Anal. Cal., 84: 441-445.

Coats, A.W. and J.P. Redfern, 1964. Kinetic parameters from thermogravimetric data. Nature, 201: 68-69.

Dias, V.C., J. Lucien, D.F. Legatt and R.W. Yatscoff, 1995. Measurement of the active leflunomide metabolite (A77 1726) by reverse-phase high-performance liquid chromatography. Ther. Drug Monit., 17: 84-88.

Fairbanks, L.D., E. A. Carrey, K. Ruckemann, R. Swaminathan, B. Kirschbaum and H.A. Simmonds, 1999. Simultaneous separation by high-performance liquid chromatography of carbamoyl aspartate, carbamoyl phosphate and dihydroorotic acid. J. Chromatogr., 732: 487-493.

Giron, D., 2002. Applications of thermal analysis and coupled techniques in pharmaceutical industry. J. Therm. Anal. Cal., 68: 335-357.

Hatakeyama, T. and Z. Liu, 1998. Hand Book of Thermal Analysis. John Wiley and Sons Ltd., London.

Horowitz, H.H. and G. Metzeger, 1963. A new analysis of thermogravimetric traces. Anal. Chem., 35: 1464-1468.

Huang, Y., Y. Cheng, K. Alexander and D. Dollimore, 2001. The thermal analysis study of the drug captopril. Thermochim. Acta, 367-368: 43-58.

Manna, S.K. and B.B. Aggarwal, 1999. Immunosuppressive leflunomide metabolite (A77 1726) Blocks TNF-dependent nuclear factor-?B activation and gene expression. J. Immunol., 162: 2095-2102.

Martindale, W., 2009. The Complete Drug Reference, the Extra Pharmacopeia. 36 Edn., Pharmaceutical Press, London, Chicago.

Mashru, R.C., V.B. Sutariya, M.G. Sankalia and P. Yagnakumar, 2005. Characterization of solid dispersions of rofecoxib using differential scanning calorimeter. J. Thermal Anal. Calorimetry, 82: $167-170$.

Ning, L. and $\mathrm{L}$. $\mathrm{Xu}, 2010$. Thermal analysis of $\beta$-cyclodextrin/Berberine chloride inclusion compounds. Thermochemica Acta, 499: 166-170.

Ozawa, T., 2000. Thermal analysis-review and prospect. Thermochim. Acta, 355: 35-42.

Roon, E.N., J.P. Yska, J. Raemaekers, T.L.T.A. Jansen, M. Wanrooy and J.R.B.J. Brouwers, 2004. A rapid and simple determination of A77 1726 in human serum by high-performance liquid chromatography and its application for optimization of leflunomide therapy. J. Pharm. Biomed. Anal., 36: 17-22. 
Saliva, M.A.S., R.G. Kelmann, T. Foppa, A.P. Cruz and F.S. Murakami et al., 2007. Thermoanalytical study of fluoxetine hydrochloride. J. Thermal Anal. Calorimetry, 87: 463-467.

Schmidt, A., B. Schwind, M. Gillich, K. Brune and B. Hinz, 2003. Simultaneous determination of leflunomide and its active metabolite, A77 1726, in human plasma by high-performance liquid chromatography. Biomed. Chromatogr., 17: 276-281.

USP, 2009. The United States Pharmacopoeia Convention. USP, Rockville, MD.
Vega, D., A. Petragalli, D. Fernandez and J.A. Ellena, 2006. Polymorphism on leflunomide: Stability and crystal structures. J. Pharmac. Sci., 95: 1075-1083.

Xu, F., L.X. Sun, Z.C. Tan, J.G. Liang and J. Zhang, 2006. Adiabatic calorimetry and thermal analysis on acetaminophen. J. Thermal Anal. Calorimetry, 83: 187-191.

Yenicelia, D., D. Dogrukol-Aka and M. Tuncela, 2005. Determination of leflunomide in pharmaceutical tablets by flow-injection analysis. J. Liq. Chromatogr. Relat. Technol., 28: 1693-1701. 